\author{
Marzena Kordela \\ Adam Mickiewicz University in Poznań, Poland \\ ORCID: 0000-0002-9785-9529 \\ kordela@amu.edu.pl
}

\title{
Inter- and Extra-Legal Axiology
}

\author{
Wewnętrzna i zewnętrzna aksjologia prawna
}

\section{SUMMARY}

The legal order is composed not only of legal norms but also of values. An axiological aspect of law becomes important especially in the acts of law interpretation and application. By reconstructing values a legislator presumes there is a possibility to reconstruct his complete axiological system. This system contains three types of values: legally binding values inbuilt in legal norms (especially in principles), reference values (this kind of values must be applied by courts in accordance with reference provisions) and universal values.

Keywords: legal axiology; value; legally binding values; reference values; universal values; axiological rationality of a legislator; axiological system of law

Law defined as a specific whole primarily takes the form of a normative being. Regardless of whether it is recognized either abstractly and statically as a system, or specifically and dynamically as a legal order - the effect of acts of law application, implementation and enforcement, in both cases direct or indirect components of a directive characteristic are distinguished: norms of conduct, rules, principles, political directives, normative acts, policies for the creation and application of law, patterns of evaluation and criticism of law ${ }^{1}$. However, even in these last types of references to law - patterns of evaluation and criticism of law - there appears an element that turns out to be inalienable in its analysis: values².

1 K. Opałek, Z teorii dyrektyw i norm, Warszawa 1974, pp. 99-101, 128-130; idem, Normy w świetle ogólnej teorii dyrektyw i norm, [in:] K. Opałek, J. Wróblewski, Prawo. Metodologia, filozofia, teoria prawa, Warszawa 1991, pp. 187-198.

2 M. Borucka-Arctowa, O społecznym działaniu prawa, Warszawa 1967, pp. 159-173; eadem, Spoleczne funkcje prawa formulowane w doktrynie, ustawodawstwie i orzecznictwie, [in:] Społeczne 
It is the values and the statements expressing them (evaluations ${ }^{3}$, axiological propositions ${ }^{4}$, evaluative judgements ${ }^{5}$ ) that underlie law-making decisions, are embedded in the texts of normative acts in the form of preambles, general principles, explicit qualification of certain states of affairs as valuable or through the use of general reference clauses or indeterminate phrases ${ }^{6}$, they perform the function of a necessary tool for law interpretation, give the final shape to the acts of law application, and finally build patterns of its evaluation and criticism external to the positive law system.

A widespread recognition in modern legal sciences of values and, more broadly, axiological issues as autonomous research objects invariably evokes contentious issues regarding the ontological status of values and the methods of ascertaining and recognizing them ${ }^{7}$. Characteristically, at present, the seriousness of these disputes has considerably softened, and this seems to be caused, first of all, by agreement on the basic catalogue of values, which are universal not only for Western culture, whose explicit legal protection is simultaneously the protection of global order $^{8}$, and, secondly, by the practice, which is becoming more visible, of naming directly in legal regulations, and not just in preambles, certain valuable states of affairs - as "values" .

poglady na funkcje prawa, red. M. Borucka-Arctowa, Wrocław-Warszawa-Kraków-Gdańsk-Łódź 1982, p. 14.; eadem, Społeczne działanie prawa, [in:] Prawo socjalistyczne. Wspótczesne problemy, red. H. Rot, Wrocław-Lódź 1989, pp. 307-309; L. Leszczyński, Podejmowanie decyzji prawnych. Tworzenie i stosowanie prawa, Zamość 2003, p. 17. See also, e.g.: "Formulating directive content of norms - spontaneous and/or intentional - in such a way that compliance with them leads to the best possible achievement (protection, multiplication) of specific values-goals, is the fulfilment of the norm-making function of values. The more the values are social (commonly shared) and the more they are considered important in society, the more often - in Habermas's language »they are embodied in the norms «. In other words, they stimulate and direct norm-making processes" (K. Pałecki, Prawoznawstwo. Prawo w porzadku społecznym, Warszawa 2003, p. 83).

3 K. Opałek, $Z$ teorii..., p. 84.

4 T. Czeżowski, O przedmiocie aksjologii, [in:] idem, Pisma z etyki i teorii wartości, WrocławŁódź 1989, p. 115.

5 Idem, Jak budować logikę dóbr?, [in:] idem, Filozofia na rozdrożu, Warszawa 1965, p. 130.

6 L. Leszczyński, Zagadnienia teorii stosowania prawa. Doktryna i tezy orzecznictwa, Kraków 2001, pp. 43-45, 169-172, 174-175.

7 See, e.g., the conception of values and their role in legal discourse in: M. Lebech, On the Problem of Human Dignity. A Hermeneutical and Phenomenological Investigation, Würzburg 2009, pp. 261-274, 275-289.

8 Although there is much more the rule than the exemption to find different relations of preference between values. See, e.g., the different position of the rule of law value in the legal culture of Japan in comparison to the Western states legal orders: L. Leszczyński, Zjawisko prawne w kulturze społecznej Japonii, „Studia Prawnicze” 1991, nr 1, p. 52-54. Cf. A. Kość, Prawo a etyka konfucjańska w historii myśli prawnej Chin, Lublin 1998, e.g. p. 202, 208, 2011; idem, Filozoficzne podstawy prawa japońskiego w perspektywie historycznej, Lublin 2001, p. 175; L. Chen-Shan, Tolerance and Constitutional Law, [in:] Wertpluralismus, Toleranz und Recht. Gedächtnisschrift für Arthur Kaufmann, Wu-Nan 2004, p. 407.

9 See, in particular, Article 2 of the Treaty on European Union: "The Union is founded on the values [emphasis - M.K.] of respect for human dignity, freedom, democracy, equality, the rule of 
Values cannot be included in any ontological category in which they are usually placed, in particular they are not the properties of objects (persons, things, phenomena, processes, etc.), because if they play a role of the part of predicates in the sentences they do not add anything to the previous content of the names of these objects. From the traditional perspective, values are transcendentals (universals), and they are attributed to objects as qualifications stated in modal propositions such as: "It is fair that $X$ (e.g. judgement) has a given content"; "It is bad that $X$ does not meet the standards of the rule of law". Thanks to this perspective, it becomes possible to adopt a position of logical objectivism in relation to axiological issues: values not only can be objectively demonstrated, but they are also directly - as "values" - named, and thus the possibility of analyzing them scientifically in the strict sense of the word arises ${ }^{10}$.

The values (evaluations ${ }^{11}$ ) present in law and in legal discourse are ordered in various ways by legal sciences. One of such divisions is a division into "internal values" and "external values" ${ }^{2}$. "The law in force expresses in its norms certain sets of values which it is to serve, and which are axiological justification of legal norms being established. We call them »internal « values of law"13. These values include, first and foremost, justice, fairness, specific political goals, protection and development of a particular morality ${ }^{14}$, as well as the rule of law, certainty, objectivity and rationality ${ }^{15}$. The other category - external values - consists of those values that belong to extra-legal axiological systems. This collection contains political values, ethical values, values of justice, as well as praxeological values (e.g. promptness and certainty of decisions in the sphere of law application) ${ }^{16}$.

The characteristic feature of both value catalogues is that the boundary between them is not and cannot be sharp. Having the character of so-called axiological mar-

\footnotetext{
law and respect for human rights, including the rights of persons belonging to minorities. These values are common to the Member States [emphasis-M.K.] in a society in which pluralism, non-discrimination, tolerance, justice, solidarity and equality between women and men prevail". See also national acts, e.g., Article 3 section 3 of the Romanian Constitution of 1991: "Romania is a democratic and social state, governed by the rule of law, in which human dignity, the citizens' rights and freedoms, the free development of human personality, justice and political pluralism represent supreme values [emphasis - M.K.] and are guaranteed".

10 T. Czeżowski simply calls it "moral empiricism". Cf. T. Czeżowski, Konflikty w etyce, [in:] idem, Filozofia ..., p. 124.

${ }^{11}$ Understood here as the result of the process of evaluating an object (state of affairs, thing, conduct, norm, etc.).

12 J. Wróblewski, Problematyka badawcza stosowania prawa, [in:] W. Lang, J. Wróblewski, S. Zawadzki, Teoria państwa i prawa, Warszawa 1979, p. 415.

13 Ibidem.

${ }_{14}$ Idem, Sadowe stosowanie prawa, Warszawa 1988, p. 82.

${ }^{15}$ Ibidem, p. 335.

${ }^{16}$ Idem, Problematyka badawcza ..., p. 416; idem, Sadowe stosowanie..., p. 83.
} 
gin ${ }^{17}$ with common tangent points, it enables mutual interaction of intra-legal ${ }^{18}$ and external axiology ${ }^{19}$. This can be seen even at the terminology level. On the one hand, the value of justice is qualified as an internal value of law and assumes the form of primarily social justice at the level of texts of normative acts and statements of judicature and doctrine (Article 2 of the Polish Constitution) ${ }^{20}$, procedural justice ${ }^{21}$, formal (abstract) justice often equated with equality ${ }^{22}$, or "justice under the law" as legality ${ }^{23}$. On the other hand, it is justice that fulfills the basic function of an external pattern for evaluating law and its application ${ }^{24}$. This axiological continuum ${ }^{25}$ means that the role of tools controlling both the source of quoted values (values as the effect of a law-making act and values outside the formally determined sphere of establishing) increases, as well as the adequacy of their use and the importance of argumentation in the acts of law application.

One of the methodologically possible ways to build a model of functioning and application of values in law that creates a pattern for checking axiological correctness of both the acts of creating law as well as its interpretation, application and enforcement, is the concept of the legislator's axiological system built in the form of a "three-layer" set with the class of legally binding values at its core.

This concept refers to the general principle of rationality and its specific form in legal sciences - the principle of rationality of the legislator. In accordance with this principle, if a legislator accepts some given knowledge and has given preferences, they undertake such action from among those available (in light of this knowledge) that unfailingly leads to the state of affairs that is the most strongly preferred. The legislator as a rational subject is consistently governed in their activity by two types of patterns:

${ }^{17}$ L. Leszczyński, Elastyczność stosowania prawa a wartości sprawiedliwości i stuszności, [in:] A. Korybski, L. Leszczyński, Stanowienie i stosowanie prawa. Elementy teorii, Warszawa 2015, p. 172.

18 The law axiology itself is a component of "the axiology of the socio-economic system in which law operates" (J. Wróblewski, Sąowe stosowanie prawa ..., p. 337).

19 See, in particular, L. Leszczyński, Otwieranie treści prawa, [in:] idem, Tworzenie generalnych klauzul odsyłających, Lublin 2000, pp. 164-167.

${ }^{20}$ Z. Ziembiński, Sprawiedliwość społeczna jako pojęcie prawne, Warszawa 1996, passim.

${ }^{21}$ Idem, Sprawiedliwe procedury rozstrzygania, [in:] idem, O pojmowaniu sprawiedliwości, Lublin 1992, pp. 175-181; M. Borucka-Arctowa, Zaufanie do prawa jako wartość spoleczna i rola sprawiedliwości proceduralnej, [in:] Teoria prawa. Filozofia prawa. Wspótczesne prawo i prawoznawstwo, Torun 1998, p. 20.

${ }_{22}$ Ch. Perelman, O sprawiedliwości, Warszawa 1959, p. 37.

23 J. Wróblewski, Sąowe stosowanie..., p. 339.

${ }^{24}$ L. Leszczyński, Wartości stosowania prawa, [in:] A. Korybski, L. Leszczyński, op. cit., p. 167; J. Wróblewski, Sądowe stosowanie..., p. 339.

${ }^{25}$ L. Leszczyński, Elastyczność stosowania prawa ..., p. 172. 
1) a non-contradictory knowledge system, and

2) a coherent, stable class of values, built preferentially ${ }^{26}$.

Values attributed to the legislator constitute a whole which cannot be reduced to simple multiplicity. Organized according to analogous rules, similarly to binding legal norms, values have the character of the elements of the system. A legislator's axiological system is composed of three subsystems:

1) legally binding values,

2) reference values, and

3) universal values.

Legally binding values have characteristic traits:

- they become legally binding by virtue of the act of enactment ${ }^{27}$,

- they constitute a certain type of value that is different from moral, customary, religious or any other values,

- it is of no importance whether a given legal value was previously defined as a moral or customary value; legislative fiat has a decisive character for its qualification.

Reference values are those that must be applied by a court in accordance with the legislator's command formulated in the reference provisions. A provision contains a general reference provision if, on its basis, a court acquires the competence to be guided by the individual evaluations of a given situation (general reference provisions type $\mathrm{I})^{28}$ or non-legal principles that are axiologically justified in general evaluations (general reference provisions type II) ${ }^{29}$, such as e.g. principles of social coexistence, or the principles of fairness.

Reference values do not have the character of values that are legally binding. The fact that the courts are obliged to apply them makes them "inbuilt" into the legal order. These are values such as: social interest, public interest, fairness, requirements of good faith, as well as justified reasons or established habits. The ascertainment of those values as being binding - although not widely acknowledged $^{30}$ - stems from the empirical observation that "people accept certain values as elementary or universal and demand that they are realized"31.

${ }^{26}$ L. Nowak, Interpretacja prawnicza. Studium z metodologii prawoznawstwa, Warszawa 1973, p. 39; Z. Ziembiński, Two Concepts of Rationality in Legislation, "Rechtstheorie" 1985, Nr. 5, pp. 147-150; idem, Theory of Sources of Law and Legal Policy, "Archiv für Rechts- und Sozialphilosophie" 1992, Nr. 54, pp. 114-115.

27 See, e.g., M. Lebech, European Sources of Human Dignity. A Commented Anthology, Oxford 2019, p. 309.

${ }_{28}$ Z. Ziembiński, Teoria prawa, Warszawa-Poznań 1978, p. 144; L. Leszczyński, Stosowanie generalnych klauzul odsyłających, Kraków 2001, p. 21.

29 Z. Ziembiński, Teoria ..., p. 144.

${ }_{30}$ M. Ossowska, Zagadnienie powszechnie uznanych norm moralnych, [in:] eadem, Socjologia moralności. Zarys zagadnień, Warszawa 1986, pp. 162-192.

31 J. Woleński, J. Hartman, Wiedza o etyce, Warszawa 2008, p. 23. 
Systems of legal values, reference values and universal values are arranged in a ring-like fashion:

- an axiological core in the form of legal values,

- reference values surround the primary set,

- the "outermost" layer of the legislator's axiological system made up of universal values.

The premise of rationality of the legislator in the order of values takes the form of a premise of axiological rationality. The legislator as a rational axiologist not only creates - as legally binding - individual values but also organizes them hierarchically ${ }^{32}$. An elementary criterion for determining the subsequent levels of its axiological system is the legal force of binding norms on the basis of which these values are reconstructed. Values in the strict sense of the word primary are constitutional values because they are not and cannot be legitimized either in terms of content or competence (formally) by any values of a higher order. A lower level is occupied by statutory values, subordinated to the former as their concretization (specification) and meeting the minimum condition necessary to maintain the cohesion and coherence of the legal system: not being incompatible with constitutional values. The same condition of non-inconsistency must be fulfilled by all the other legally binding values in the chain of descendence of legislative competences: values expressed in executive regulations to statutes, or values of acts of an internal character, regardless of whether the authors of these acts are public authorities at central, regional or local level.

By ordering values into a form suited for their pragmatical application, the legislator also makes use of such of their characteristics of which legal norms are devoid.

Almost every value is gradable. For instance, the value of justice of law is a continuum. A given positive law (as an entire system, branch of law, given normative act, or even an institution or a particular legal norm) can, therefore, be qualified as just (firmly); as just in some respects, but questionable in others; as doubtfully just; as unequivocally unjust, at least in the perception of a certain category of addressees in relation to a particular category of cases; as unjust, because it clearly discriminates against at least some group of its subjects; ultimately - radically unjust to such a level that institutions that legitimize disobedience to the law (the Radbruch formula; German doctrine of the right to resist; American doctrine of "civil disobedience") are applicable.

Similar force stratification - from the value at the highest level of its implementation to the value at the lowest level - is also built in relation to other legal values. It allows to build hierarchy of values within legal norms of the same legal force.

${ }^{32}$ M. Kordela, Zarys systemu aksjologicznego w orzecznictwie Trybunatu Konstytucyjnego, „Ruch Prawniczy, Ekonomiczny i Socjologiczny” 2001, nr 1-2, p. 67; eadem, , Lex” " , ,ius ” w orzecznictwie Trybunału Konstytucyjnego, ,Ius et Lex” 2002, nr 1, p. 221. 
This is particularly visible in the case of constitutional norms. From a formal point of view, all constitutional values belong to an identical, internally undifferentiated set. Although sometimes the legislator himself extracts some of the provisions of the constitution and grants them the status of unchangeable, indicating their superiority over the others, or the legal science builds analogous constructions in terms of their effect, e.g. in the form of functionally superior constitutional principles ${ }^{33}-$ in both these situations there is a kind of intervention from outside the law axiology. On the other hand, the very essence of values and the whole they build gives grounds for reconstructing, e.g. the fact that the constitutional principle of equality has a higher position than the constitutional principle of equality between women and men, although both are in the same normative act, they concern exactly the same dimension of regulation, and the second is simply a specification of the first.

Another unique feature of values is their immanent colliding nature ${ }^{34}$. And of course, it is not the question of simply classic opposition between positive and negative values, such as justice vs injustice or freedom vs slavery. Conflicting nature of values is manifested in the fact that the maximum realization of, e.g., property values inevitably leads to violation and even the elimination of other legally protected values, e.g. another property, health, life, sense of security, social peace. All these values have the status of legally binding and undoubtedly positive. However, they cannot be equally well fulfilled. Part of the obligation to adjust conflicting values is taken by the legislator, which results in normative acts containing rules, applied in a Dworkinian "all-or-nothing" manner ${ }^{35}$. However, in situations where in view of the necessity to ensure flexibility of law, the legislator uses, for example, general reference clauses or legal principles, the competence to balance the values passes to entities applying the law, in particular to courts. Then the court has the legal obligation to reproduce the catalogue of legally relevant values, both legally binding, as is the case with the principles of law as elements of the legal system $^{36}$, as well as the reference values ${ }^{37}$. After constructing such a catalogue it is

${ }^{33}$ K. Działocha, Hierarchia norm konstytucyjnych i jej rola w rozstrzyganiu kolizji norm, [in:] Charakter i struktura norm konstytucji, red. J. Trzciński, Warszawa 1997, p. 92.

${ }^{34}$ L. Nowak, U podstaw marksistowskiej aksjologii, Warszawa 1974, p. 18.

35 R. Dworkin, The Model of Rules, [in:] Philosophy of Law, eds. J. Feinberg, H. Gross, Wadsworth 1986, p. 154.

${ }^{36}$ When assuming a definition of a principle as a legal norm that orders (forbids) realization of a given value, then demonstration of the principle in an adequate wording is simultaneously a demonstration of the given value (positive or negative) that is legally binding. Cf. M. Kordela, Zasady prawa. Studium teoretycznoprawne, Poznań 2014, p. 102. On methods of recreating legal values see, e.g., eadem, Aksjologiczna wyktadnia prawa, [in:] Polityczność nauki prawa i praktyki prawniczej, red. A. Bator, P. Kaczmarek, Wrocław 2017, p. 156.

${ }^{37}$ In particular, see L. Leszczyński, Kryteria aksjologii otwartej w wykladni prawa, [in:] A. Kalisz, L. Leszczyński, B. Liżewski, Wyktadnia prawa. Model ogólny a perspektywa Europejskiej Konwencji Praw Człowieka i prawa Unii Europejskiej, Lublin 2011, pp. 60-66. 
necessary - even if only in general terms - to reconstruct the rules of preference of these values, i.e. perform an act of attributing a certain degree of "importance/ weight" $" 38$ to these values. Only after this preliminary determination of the "axiological decision-making field" can the court make a decision. It takes place either by choosing the strongest value or by mutually agreeing on the values if they cannot all be optimally fulfilled. The fact that in each of the above stages the court has a clear sphere of decision-making discretion does not raise any doubts, but this discretion is also clearly legitimized by law. However, the most important tasks in the process of applying values - and not norms - is proper justification, first of all, of qualifying given values as relevant for a given case, second, correctly naming these values, third, assigning them a certain degree of weight, fourth, hierarchizing them, fifth, demonstrating collision, sixth, choosing the principal value or, seventh, weighing values, and eighthly, applying values harmonized by the court.

The pattern of such justification fully meets the criteria of rationality ${ }^{39}$. This does not mean, however, that it guarantees a mechanically predictable effect. But this is not guaranteed not only by values. In the history of the application of ordinary legal norms, there have been cases of controversy which to be resolved required more than just a simple act of subsumption.

\section{REFERENCES}

Alexy R., The Theory of Fundamental Rights, Oxford 2002.

Borucka-Arctowa M., O społecznym działaniu prawa, Warszawa 1967.

Borucka-Arctowa M., Społeczne działanie prawa, [in:] Prawo socjalistyczne. Wspótczesne problemy, red. H. Rot, Wrocław-Lódź 1989.

Borucka-Arctowa M., Spoleczne funkcje prawa formulowane w doktrynie, ustawodawstwie i orzecznictwie, [in:] Społeczne poglady na funkcje prawa, red. M. Borucka-Arctowa, Wrocław-Warszawa-Kraków-Gdańsk-Łódź 1982.

Borucka-Arctowa M., Zaufanie do prawa jako wartość społeczna i rola sprawiedliwości proceduralnej, [in:] Teoria prawa. Filozofia prawa. Współczesne prawo i prawoznawstwo, Toruń 1998.

Chen-Shan L., Tolerance and Constitutional Law, [in:] Wertpluralismus, Toleranz und Recht. Gedächtnisschrift für Arthur Kaufmann, Wu-Nan 2004.

Czeżowski T., Jak budować logikę dóbr?, [in:] idem, Filozofia na rozdrożu, Warszawa 1965.

Czeżowski T., Konflikty w etyce, [in:] idem, Filozofia na rozdrożu, Warszawa 1965.

Czeżowski T., O przedmiocie aksjologii, [in:] idem, Pisma z etyki i teorii wartości, Wrocław-Łódź 1989.

Dworkin R., The Model of Rules, [in:] Philosophy of Law, eds. J. Feinberg, H. Gross, Wadsworth 1986.

Działocha K., Hierarchia norm konstytucyjnych i jej rola w rozstrzyganiu kolizji norm, [in:] Charakter i struktura norm konstytucji, red. J. Trzciński, Warszawa 1997.

${ }^{38}$ R. Dworkin, op. cit., p. 156.

39 R. Alexy, The Theory of Fundamental Rights, Oxford 2002, pp. 50-56, 396-425. 
Kordela M., Aksjologiczna wykladnia prawa, [in:] Polityczność nauki prawa i praktyki prawniczej, red. A. Bator, P. Kaczmarek, Wrocław 2017.

Kordela M., ,,Lex” $i$,,ius” w orzecznictwie Trybunatu Konstytucyjnego, „Ius et Lex” 2002, nr 1.

Kordela M., Zarys systemu aksjologicznego w orzecznictwie Trybunału Konstytucyjnego, „Ruch Prawniczy, Ekonomiczny i Socjologiczny" 2001, nr 1-2.

Kordela M., Zasady prawa. Studium teoretycznoprawne, Poznań 2014.

Kość A., Filozoficzne podstawy prawa japońskiego w perspektywie historycznej, Lublin 2001.

Kość A., Prawo a etyka konfucjańska w historii myśli prawnej Chin, Lublin 1998.

Lebech M., European Sources of Human Dignity. A Commented Anthology, Oxford 2019.

Lebech M., On the Problem of Human Dignity. A Hermeneutical and Phenomenological Investigation, Würzburg 2009.

Leszczyński L., Elastyczność stosowania prawa a wartości sprawiedliwości i stuszności, [in:] A. Korybski, L. Leszczyński, Stanowienie i stosowanie prawa. Elementy teorii, Warszawa 2015.

Leszczyński L., Kryteria aksjologii otwartej w wykładni prawa, [in:] A. Kalisz, L. Leszczyński, B. Liżewski, Wykładnia prawa. Model ogólny a perspektywa Europejskiej Konwencji Praw Człowieka i prawa Unii Europejskiej, Lublin 2011.

Leszczyński L., Otwieranie treści prawa, [in:] idem, Tworzenie generalnych klauzul odsyłajacych, Lublin 2000.

Leszczyński L., Podejmowanie decyzji prawnych. Tworzenie i stosowanie prawa, Zamość 2003.

Leszczyński L., Stosowanie generalnych klauzul odsyłajacych, Kraków 2001.

Leszczyński L., Wartości stosowania prawa, [in:] A. Korybski, L. Leszczyński, Stanowienie i stosowanie prawa. Elementy teorii, Warszawa 2015.

Leszczyński L., Zagadnienia teorii stosowania prawa. Doktryna i tezy orzecznictwa, Kraków 2001.

Leszczyński L., Zjawisko prawne w kulturze społecznej Japonii, „Studia Prawnicze” 1991, nr 1.

Nowak L., Interpretacja prawnicza. Studium z metodologii prawoznawstwa, Warszawa 1973.

Nowak L., U podstaw marksistowskiej aksjologii, Warszawa 1974.

Opałek K., Normy w świetle ogólnej teorii dyrektyw i norm, [in:] K. Opałek, J. Wróblewski, Prawo. Metodologia, filozofia, teoria prawa, Warszawa 1991.

Opałek K., Z teorii dyrektyw i norm, Warszawa 1974.

Ossowska M., Zagadnienie powszechnie uznanych norm moralnych, [in:] eadem, Socjologia moralności. Zarys zagadnień, Warszawa 1986.

Pałecki K., Prawoznawstwo. Prawo w porzadku społecznym, Warszawa 2003.

Perelman Ch., O sprawiedliwości, Warszawa 1959.

Woleński J., Hartman J., Wiedza o etyce, Warszawa 2008.

Wróblewski J., Problematyka badawcza stosowania prawa, [in:] W. Lang, J. Wróblewski, S. Zawadzki, Teoria państwa i prawa, Warszawa 1979.

Wróblewski J., Sadowe stosowanie prawa, Warszawa 1988.

Ziembiński Z., Sprawiedliwe procedury rozstrzygania, [in:] idem, O pojmowaniu sprawiedliwości, Lublin 1992.

Ziembiński Z., Sprawiedliwość społeczna jako pojęcie prawne, Warszawa 1996.

Ziembiński Z., Teoria prawa, Warszawa-Poznań 1978.

Ziembiński Z., Theory of Sources of Law and Legal Policy, “Archiv für Rechts- und Sozialphilosophie" 1992, Nr. 54.

Ziembiński Z., Two Concepts of Rationality in Legislation, "Rechtstheorie" 1985, Nr. 5. 
Pobrane z czasopisma Studia Iuridica Lublinensia http://studiaiuridica.umes.pl Data: 26/04/2023 10:20:49

\section{STRESZCZENIE}

Porządek prawa składa się nie tylko z norm, lecz także z wartości. Aksjologiczny aspekt prawa staje się ważny zwłaszcza w przypadku jego interpretacji i stosowania. Rekonstruując wartości, prawodawca zakłada, że istnieje możliwość zrekonstruowania całego systemu aksjologicznego. System ten obejmuje trzy rodzaje wartości: prawnie wiążące wartości wbudowane w normy prawne (szczególnie w zasady), wartości odesłania (tego rodzaju wartości muszą być stosowane przez sądy zgodnie z odesłaniami) i wartości uniwersalne.

Słowa kluczowe: aksjologia prawna; wartość; wartości wiążące prawnie; wartości odesłania; wartości uniwersalne; aksjologiczna racjonalność ustawodawcy; aksjologiczny system prawa 